\title{
A Further Examination of the Relationship between Contract Administration Problems and Contract Type
}

\author{
Bill Davison \\ Stearns County Minnesota, United States \\ Richard J Sebastian \\ Professor Emeritus of Management \\ St. Cloud State University
}

Tina M Borger

National Institute of Government Purchasing

Received: Oct. 4, 2012

Accepted: December 29, 2012 Published: January 1, 2013

doi:10.5296/jmr.v5i1.2497

URL: http://dx.doi.org/10.5296/jmr.v5i1.2497

\begin{abstract}
This new research supports the 2006 research conducted by Davison and Sebastian (Davison-Sebastian 2007) that data is available for, each type of contract, the likelihood of contract administration problems occurring and the consequences of these problems if they do occur. With this data the procurement professional can utilize a traditional risk management process to determine an overall risk factor for each problem and then develop proactive risk mitigation plans that are based on eliminating or reducing each of the previously identified risks, or problems that have been identified. The major findings were that the 2011 results were comparable to 2006 in that when contract administration problems occurred, problematic consequences were more likely than no consequences for all contract types except leases and that the types of problematic consequences that were most likely depended on the type of contract. The implications of the research results for procurement professionals and the limitations of the research will be discussed.
\end{abstract}

Keywords: Contract administration problems, Risk management, Contract types, Critical Risk Factors, Vendor Performance, Risk Mitigation, Contract Management 


\section{Introduction}

\section{Background - Previous Research}

\section{Goals}

The goal of the procurement of any good or service is successful contract completion. Successful contract completion is defined by the National Institute of Government Purchasing (NIGP) as successful procurement of the right item, in the right quantity, for the right price, at the right time, with the right quality, from the right source. (Thai, 2004).

Contract Administration has been described as "putting the teeth in project monitoring and control" (Reardon 2009b). The Government Accounting Office (GAO) has identified both project management and contract management as deficiencies in Department of Defense contracts (GAO, 2005). This has led to increased interest in developing tools, such as, the Contract Management Maturity Model (CIMM), to measure the contract management process capabilities of an agency and the similarities the project Management and contract management share with organizational critical success factors. (Rendo)

In their initial research Authors proposed that "advance knowledge of the likelihood of occurrence and the severity of consequences will allow procurement professionals to identify the likely contract administration problems for a specific contract type" (Authors, 2009b). From this, procurement professionals could proactively identify and prepare for known contract risks, work with suppliers throughout the contract to mitigate problems, and ultimately avoid the waste of valuable resources normally spent reacting to problems. They conclude that with this knowledge, and the ability to apply it appropriately, procurement professionals can demonstrate the "strategic value of procurement" through streamlining procurement (Authors, 2009b).

\section{Risks in Procurement}

While there are numerous items and services that can be purchased, each purchase of goods and services faces the same set of contractual risks that affect the successful accomplishment of any of the five "5 R's.” Abi-Karam (2002) suggested that every purchase should be evaluated for six types of risks: Proposal risk, Surety and liability risks, Schedule risk, Contractual risk, Performance risk and Price risk.

Davison and Wright (2004) expanded on the definition of these risks to include their relationship to the " 5 R's":

- Proposal risk: The legal document that defines the item or service procured (the right item), the mutual areas of agreement, and how risks will be allocated and rewarded.

- Surety and liability risks: Protection of the agency's financial and legal interests (the right price). The contract will define the insurance requirements, bonding requirements, and licensing that are necessary to protect the agency in the event of contract termination or to meet statutory requirements. 
- $\quad$ Schedule risk: Ensuring timely delivery (the right time). The contract will contain clear and specific language describing the contract deliverables, delivery terms, and any penalties for late delivery.

- $\quad$ Contractual risk: Establishing change order procedures, dispute resolution process and termination procedures (the right price and time).The contract is a living document and allowances must be made to accommodate unforeseen conditions that may affect the purchase. The contract will specify who has the authority to make changes, how changes will be made, and what changes will be unilateral. The contract will specify how disputes will be resolved if mutual agreement cannot be reached. The contract will specify the termination process.

- Performance risk: Defining acceptance (the right quality). The contract will define the conditions under which acceptance will occur and what type of inspection will be required.

- $\quad$ Price risk: Defining payment terms (the right price). The contract will define how and when the Contractor will be paid.

\section{Contract problems}

Based on observation and communication with peers, Davison (2004) proposed that each of these 6 contractual risks is comprised of a set of contract problems that may occur each time the good or service is procured (Table 1). Each contract problem that occurs can threaten the success of the project by impacting any or all of the 5 "R' $s$ " in an adverse manner, such as, delivery of incorrect product, incorrect quantity, an increase in project costs, a delay in delivery, poor quality or the ultimate unsuccessful result, contract termination (Davison \& Wright, 2004).

Table 1. Contract Administration Problems

\begin{tabular}{|l|l|}
\hline $\begin{array}{l}\text { Contract } \\
\text { Problem }\end{array}$ & Examples \\
\hline Wrong product & $\begin{array}{l}\text { Purchase order or contract clearly identifies correct product, but vendor ships incorrect. No } \\
\text { dispute involved }\end{array}$ \\
\hline Delay & $\begin{array}{l}\text { Purchase order has clearly stated completion date. Completion date delayed (any length of time) } \\
\text { due to agency or vendor (with or without cause). }\end{array}$ \\
\hline $\begin{array}{l}\text { Change order } \\
\text { conflict }\end{array}$ & $\begin{array}{l}\text { Change in the scope of work (additional work, money, time), after contract award. Can be } \\
\text { requested by either party for any reason. }\end{array}$ \\
\hline $\begin{array}{l}\text { Personality } \\
\text { employees. Disagreement between the parties that can not be easily resolved. May involve scope } \\
\text { of work, materials supplied, payment schedules, or any other aspect of the contract. }\end{array}$ \\
\hline $\begin{array}{l}\text { Poor } \\
\text { performance }\end{array}$ & $\begin{array}{l}\text { Completion of project is delayed due to non acceptance of final product. Example: difference in } \\
\text { either party's definition of what was supposed to be delivered or provided }\end{array}$ \\
\hline Sub- & $\begin{array}{l}\text { Contract clearly states a level of expected performance (this is not in dispute) and quality } \\
\text { problems with vendor's performance of work occur. }\end{array}$ \\
\hline
\end{tabular}




\begin{tabular}{|l|l|}
\hline Contractors & approval, for use of subcontractors, was received \\
\hline Other sources & There are very few vendors that can perform the work. \\
\hline Risk of failure & $\begin{array}{l}\text { The project has a high risk of failure. i.e. new technology, new equipment, new vendor, Project } \\
\text { never been done before. Tight timeline or budget }\end{array}$ \\
\hline Cost & Project has a high cost. \\
\hline
\end{tabular}

\section{Mapping of Goals, Risks and Contract Problems}

The following table (Table 2) maps the relationship between procurement goals, risks and contract problems (Davison-Sebastian-PWGSC 2011) .

Table 2. Mapping of Goals, Risks and Contract Problems

\begin{tabular}{|l|l|l|}
\hline Goal Criteria & Risk & Contract Problem \\
\hline $\begin{array}{l}\text { Right Item and Right } \\
\text { Quantity }\end{array}$ & Proposal Risk & $\begin{array}{l}\text { Poor Performance; Risk of Failure; } \\
\text { Final Acceptance }\end{array}$ \\
\hline Right Price & $\begin{array}{l}\text { Surety and liability risk; } \\
\text { Contractual Risk; } \\
\text { Price Risk }\end{array}$ & $\begin{array}{l}\text { Cost; } \\
\text { Change Order; Personality Conflict }\end{array}$ \\
\hline Right Time & $\begin{array}{l}\text { Schedule Risk; } \\
\text { Contractual Risk }\end{array}$ & $\begin{array}{l}\text { Wrong product; Delay; } \\
\text { Change Order; Personality Conflict }\end{array}$ \\
\hline Right Quality & Performance Risk & $\begin{array}{l}\text { Final Acceptance; Poor Performance; Risk of } \\
\text { Failure; Subcontractors }\end{array}$ \\
\hline Right Source & Surety and liability risk & $\begin{array}{l}\text { Cost; } \\
\text { Subcontractors; } \\
\text { Other Sources; } \\
\text { Risk of Failure }\end{array}$ \\
\hline
\end{tabular}




\section{Identifying Contract Types}

Based on observation and communication with peers and after reviewing the set of contractual risk characteristics for the purchase of each good or service, Davison proposed that each purchase can be placed into one of seven contract types (Table 3) (Davison \& Wright, 2004) and that each of these contract type shares a similar set of contractual risks and potential contract administration problems (Table 3). (Davison \& Wright, 2004). This study empirically tested the validity of the conceptual framework offered in Table 4.

Table 3. Contract Types

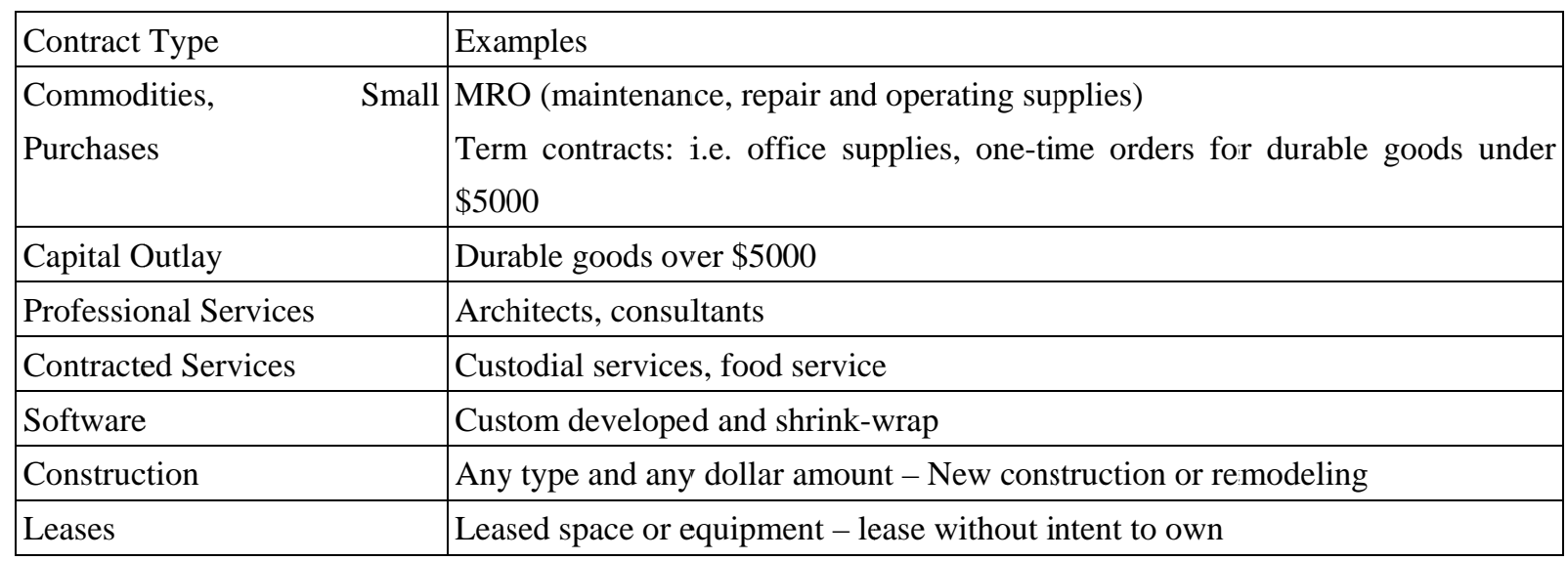

\section{Limitations of Previous Research}

In 2006 the Authors guided by a conceptual model developed by Davison and Wright (Davison-Wright 2004), surveyed members of the National Institute of Government Purchasing (NIGP) and Institute of Supply Management to determine if there was relationship between contract type and problems likely to occur. (Davison-Sebastian 2007). The results of the 2006 survey provided partial support for the for the perceived relationship of the occurrence of contract administration problems for the various contract types provided partial support for the conceptual model. Low response rate and the fact that the raw data collected were in reality ratings and not ranks were identified as a limitations in the 2006 research.

At the agency level there may be no means to collect data electronically on the contract administration problems encountered. The absence of these hard data may have contributed to the respondents' inability to rank order the frequency with which the ten types of problems occurred for each type of purchase. In addition, the survey respondents are probably more familiar with rating scales than ranking. Thus, though they did use intermediate values in their responses, they more frequently used the extreme values, 1 and 10, in particular as ratings of the perceived occurrence of the various problems.

In 2010, using the 2006 survey instrument as a base, Authors surveyed members of Public Works and Government Services Canada (PWGSC) (2010) to replicate the previous study, to assess the general validity of the original findings and to expand the overall empirical base. To 
address the previous limitation of using reality rankings instead of ranks, in the 2010 survey instrument, the question for likelihood of occurrence was posed as one of ordinal ratings instead of relative rankings. (Davison, B. \& Sebastian, R.J. \& Public Worlks and Government Services Canada (PWGSC), (2011)

The study achieved the objective of creating a larger, cross-border pool of results. Low response rate was identified as a limitation of this survey.

Based on feedback provided by the 2010 PWGSC respondents, the low overall response rate may have been because completion of the survey turned out to be more time consuming and difficult than anticipated. For the 2011 NIGP research, the survey document was redesigned using skip logic to reduce the number of questions presented to all respondents. All respondents were presented with three (3) demographic questions-- country, entity type, and position--and then asked if they are involved in post-award activities, with the survey ending for those who were not. Additional skip logic was introduced for respondents who had not issued purchase orders or contracts for a particular category of goods and services (capital outlay, professional services, contracted services, software, leases, and construction), greatly reducing the number of applicable questions to answer. In addition, in recognition of the complexity of the survey and the time limitations of the target audience, respondents had the option to start, stop, and reopen the survey to finish at a later time. For the 2010 PWGSC and 2011 NIGP survey, the same definitions of the seven major contract purchase types and ten major contract management problems were used. Using the same definitions the 2010 and 2011 respondents were then asked to indicate the frequency with which these problems occur for each type of contract by using a rating scale. The survey was then sent to all of the members of the National Institute of Government Purchasing (NIGP) again in 2011.

\section{Method}

\section{Subjects and Procedure}

The subjects were the members of the National Institute of Governmental Purchasing, Inc. (NIGP) as extracted from the membership database on December 29, 2011 ( $\mathrm{N}=14,723)$. Of these, 233 records did not include email addresses and 648 had previously opted out of SurveyMonkey, resulting in 13,842 individual email addresses successfully uploaded to SurveyMonkey. An email with a link to the survey was sent through SurveyMonkey to each of these email addresses on January 5, 2012, and included the following preface:

NIGP has partnered with Authors to study the relationship between the type of items or services procured and the problems typically encountered during contract administration.

The results may help procurement professionals anticipate the types of administration problems that are likely to occur for specific types of purchases. This information, in turn, will help procurement professionals develop plans to avoid the problems or minimize their potential negative consequences.

The survey could take up to 20 minutes to complete, depending on how involved you are in Contract Administration. You have the option to start the survey and stop, and then reopen the 
survey to finish it at a later time. When answering the questions, use your experience and recollection or actual data if you have them.

Please note that questions marked with "*" (an asterisk) require an answer to continue with the survey.

Your responses will be tabulated by St. Cloud University support personnel and will be completely confidential and anonymous.

Of the 13,842 emails sent, 64 were undeliverable, and, upon receipt of the email invitation, another 56 people opted out of SurveyMonkey, leaving a total of 13,722 sent emails.

A reminder email was sent to all those who had not responded on January 11, 2012, announcing the closing date of January 13, 2012.

\section{Survey Instrument}

Both surveys asked a number of background questions, including, country in which the respondent worked, type of agency worked for, current position, total years in purchasing, years in current position, highest level of education, field of education, professional certifications currently held, year when most recent certification was obtained, approximate annual purchasing volume for the respondent's entire agency, approximate annual purchasing volume made by the respondent, respondent's level of purchasing authority, number of full time employees in respondent's agency, number of full time employees in respondent's purchasing unit, types of purchases respondent has current responsibility for, and the number of purchase orders or contracts issued by the respondent for the major contract categories investigated in the study-Commodities, Capital Outlay, Professional Services, Contracted Services, Software, Leases, Construction, and Other. The 2011 survey also asked if they were involved in post award activities such as monitoring performance, delay resolution, change orders, dispute resolution, final acceptance and monitoring performance and they were asked if their organization collected data on each of these post award activities. If respondents indicated they were not involved in any of the listed post award activities, the survey was terminated at that point. A copy of the complete survey is in Appendix A.

The 2006 survey then provided definitions of the seven major contract purchase types and ten major contract management problems-Wrong Product, Delay, Final Acceptance, Change Order, Personality Conflict, Poor Performance, Sub Contractors, Cost, Other sources, and Risk of Failure. Using these definitions, respondents were then asked to rank order the frequency with which these problems occur for each type of contract. The exact instructions for this question follow:

For purchases made within the past year, rank order the problems that apply in terms of how often they occur for each contract type with 1 being most frequent (as applicable) to 10 being least frequent (as applicable) or choose 99 for those that do not apply. Please use each of the ten ranks only once.

The 2011 survey used the same definitions of the seven major contract purchase types and ten major contract management problems. The respondents were then asked select the frequency 
with which these problems occur for each type of contract by selecting from the following responses: Never, Rarely, Sometimes, Often, Most of the Time and Always.

Lastly, for both surveys the respondents were asked to indicate the typical consequences they experienced for each type of problem within each type of contract by selecting from the following responses: No Effect, Contract Delay $<10$ days, Contract Delay $>10$ days, Increased Cost $<10 \%$, Increased Cost $>10 \%$, Contract Termination.

\section{Response Rate}

The total number of respondents from 2011 was 1661 (of 13,722), for a response rate of 12.1\% The total of the NIGP respondents from 2006 was 500 (of 10185) for a response rate of 5\%

\section{Comparison to 2006 response rate}

The number of responses for the 2011 survey, 1661, is significantly higher than 2006, 500. Of the 3 variables, target population, method of delivery and survey instrument only the survey instrument was changed. It can be tentatively concluded that the changes in the survey tool, implemented as a result of the feedback from the PWGSC survey resulted in a greater number of responses.

\section{Findings}

\section{Respondent Characteristics}

The following categories were selected to provide an appreciation of the range of respondent characteristics.

Table 4.Demographic Data

\begin{tabular}{|l|l|l|l|l|}
\hline Years in Purchasing & $11+$ & $62 \%$ & 2 or less & $3 \%$ \\
\hline Years in Current Position & $6+$ & $46 \%$ & 2 or less & $20 \%$ \\
\hline \% With 4 year degree or more & Yes & $63 \%$ & No & $37 \%$ \\
\hline Annual Individual Purchasing Volume & 5 million & $29 \%$ & 20 million & $23 \%$ \\
\hline Annual Agency Purchasing Volume & 100 million & $40 \%$ & & \\
\hline Full time employees in Agency & 1000 & $42 \%$ & 400 or less & $24 \%$ \\
\hline Full time employees in Purchasing & 5 or less & $33 \%$ & 10 or more & $31 \%$ \\
\hline Involved in some type of post award activity & Yes & $92 \%$ & & \\
\hline Some type of Procurement Professional as title of position & Yes & $95 \%$ & & \\
\hline
\end{tabular}

\section{Comparison to 2006 Respondent Characteristics}

Because response categories as opposed to open ended responses were used in the 2011 survey it is impossible to make a direct comparison to the 2006 survey, but it can be said the 2011 respondent characteristics are similar to available NIGP demographics and suggest that the sample is representative of the population. 


\section{Reported occurrence of contract problems for each contract type}

Initially, means were computed for the respondents' ratings of the indicated likelihood of occurrence of the contract problems for each of the contract types. These means were then rank ordered from most likely to least likely for each type of contract. The 2011 and 2006 results are reported in Table 6.

Table 5. Comparison of 2011 v. 2006 The Relationship between Perceilved Occurrence of Contract Administration Problems and Contract Type, Table sorted by Contract Problem Rank

\begin{tabular}{|c|c|c|c|c|c|c|c|c|c|c|c|}
\hline $\begin{array}{l}\text { Ye } \\
\text { ar }\end{array}$ & $\begin{array}{l}\text { Contract } \\
\text { Type }\end{array}$ & 1 & 2 & 3 & 4 & 5 & 6 & 7 & 8 & 9 & 10 \\
\hline $\begin{array}{l}20 \\
11\end{array}$ & $\begin{array}{l}\text { Supplies } \\
\text { and } \\
\text { Small } \\
\text { Purchas } \\
\text { es }\end{array}$ & $\begin{array}{l}\text { Change } \\
\text { Order }\end{array}$ & $\begin{array}{l}\text { Othe } \\
\mathrm{r} \\
\text { Sour } \\
\text { ces }\end{array}$ & Delay & $\begin{array}{l}\text { Poor } \\
\text { Perform } \\
\end{array}$ & High Cost & $\begin{array}{l}\text { Risk } \\
\text { of } \\
\text { Failu } \\
\text { re }\end{array}$ & $\begin{array}{l}\text { Wrong } \\
\text { Product }\end{array}$ & $\begin{array}{l}\text { Defn of } \\
\text { Accept }\end{array}$ & Conflict & $\begin{array}{l}\text { Subcon } \\
\text { tract }\end{array}$ \\
\hline $\begin{array}{l}20 \\
06 \\
\end{array}$ & $\begin{array}{l}\text { Supplies } \\
\text { and } \\
\text { Small } \\
\text { Purchas } \\
\text { es }\end{array}$ & Delays & Cost & Poor Perform & $\begin{array}{l}\text { Change } \\
\text { Order }\end{array}$ & $\begin{array}{l}\text { Wrong } \\
\text { Product }\end{array}$ & $\begin{array}{l}\text { Othe } \\
\mathrm{r} \\
\text { Sour } \\
\text { ces }\end{array}$ & Conflict & $\begin{array}{l}\text { Defn of } \\
\text { Accept }\end{array}$ & $\begin{array}{l}\text { Risk of } \\
\text { Failure/Term } \\
\text { ination }\end{array}$ & $\begin{array}{l}\text { Subcon } \\
\text { tract }\end{array}$ \\
\hline $\begin{array}{l}20 \\
11 \\
\end{array}$ & $\begin{array}{l}\text { Capital } \\
\text { Outlay }\end{array}$ & $\begin{array}{l}\text { Change } \\
\text { Order } \\
\end{array}$ & $\begin{array}{l}\text { Othe } \\
\mathrm{r} \\
\text { Sour } \\
\text { ces } \\
\end{array}$ & Delay & $\begin{array}{l}\text { High } \\
\text { Cost }\end{array}$ & $\begin{array}{l}\text { Risk of } \\
\text { Failure/Term } \\
\text { iantion }\end{array}$ & $\begin{array}{l}\text { Poor } \\
\text { Perfo } \\
\mathrm{rm} \\
\end{array}$ & $\begin{array}{l}\text { Defn of } \\
\text { Accept }\end{array}$ & $\begin{array}{l}\text { Wrong } \\
\text { Product }\end{array}$ & Conflict & $\begin{array}{l}\text { Subcon } \\
\text { tract }\end{array}$ \\
\hline $\begin{array}{l}20 \\
06 \\
\end{array}$ & $\begin{array}{l}\text { Capital } \\
\text { Outlay }\end{array}$ & Delays & Cost & $\begin{array}{l}\text { Change } \\
\text { Order }\end{array}$ & $\begin{array}{l}\text { Poor } \\
\text { Perform }\end{array}$ & $\begin{array}{l}\text { Other } \\
\text { Sources }\end{array}$ & $\begin{array}{l}\text { Conf } \\
\text { lict }\end{array}$ & Subcontract & $\begin{array}{l}\text { Defn of } \\
\text { Accept }\end{array}$ & $\begin{array}{l}\text { Risk of } \\
\text { Failure/Term } \\
\text { ination }\end{array}$ & $\begin{array}{l}\text { Wrong } \\
\text { Product }\end{array}$ \\
\hline $\begin{array}{l}20 \\
11 \\
\end{array}$ & $\begin{array}{l}\text { Professi } \\
\text { onal } \\
\text { Services }\end{array}$ & $\begin{array}{l}\text { Change } \\
\text { Order }\end{array}$ & $\begin{array}{l}\text { Othe } \\
\mathrm{r} \\
\text { Sour } \\
\text { ces }\end{array}$ & Delay & $\begin{array}{l}\text { High } \\
\text { Cost }\end{array}$ & Poor Perform & $\begin{array}{l}\text { Risk } \\
\text { of } \\
\text { Failu } \\
\text { re } \\
\end{array}$ & $\begin{array}{l}\text { Defn of } \\
\text { Accept }\end{array}$ & Conflict & $\begin{array}{l}\text { Wrong } \\
\text { Product }\end{array}$ & $\begin{array}{l}\text { Subcon } \\
\text { tract }\end{array}$ \\
\hline $\begin{array}{l}20 \\
06\end{array}$ & $\begin{array}{l}\text { Professi } \\
\text { onal } \\
\text { Services }\end{array}$ & $\begin{array}{l}\text { Change } \\
\text { Order }\end{array}$ & $\begin{array}{l}\text { Dela } \\
\text { ys }\end{array}$ & Cost & $\begin{array}{l}\text { Conflic } \\
\mathrm{t}\end{array}$ & $\begin{array}{l}\text { Defn of } \\
\text { Accept }\end{array}$ & $\begin{array}{l}\text { Poor } \\
\text { Perfo } \\
\text { rm }\end{array}$ & Subcontract & $\begin{array}{l}\text { Other } \\
\text { Sources }\end{array}$ & $\begin{array}{l}\text { Risk of } \\
\text { Failure/Term } \\
\text { ination }\end{array}$ & $\begin{array}{l}\text { Wrong } \\
\text { Product }\end{array}$ \\
\hline $\begin{array}{l}20 \\
11 \\
\end{array}$ & $\begin{array}{l}\text { Contract } \\
\text { ed } \\
\text { Services } \\
\end{array}$ & $\begin{array}{l}\text { Change } \\
\text { Order }\end{array}$ & $\begin{array}{l}\text { Poor } \\
\text { Perfo } \\
\text { rm } \\
\end{array}$ & Delay & $\begin{array}{l}\text { Other } \\
\text { Sources }\end{array}$ & $\begin{array}{l}\text { Defn of } \\
\text { Accept }\end{array}$ & $\begin{array}{l}\text { Wro } \\
\text { ng } \\
\text { Prod } \\
\text { uct } \\
\end{array}$ & Conflict & High Cost & $\begin{array}{l}\text { Risk of } \\
\text { Failure/Term } \\
\text { ination }\end{array}$ & $\begin{array}{l}\text { Subcon } \\
\text { tract }\end{array}$ \\
\hline $\begin{array}{l}20 \\
06 \\
\end{array}$ & $\begin{array}{l}\text { Contract } \\
\text { ed } \\
\text { Services } \\
\end{array}$ & $\begin{array}{l}\text { Risk of } \\
\text { Failure/Term } \\
\text { ination }\end{array}$ & $\begin{array}{l}\text { Defn } \\
\text { of } \\
\text { Acce } \\
\text { pt } \\
\end{array}$ & $\begin{array}{l}\text { Change } \\
\text { Order }\end{array}$ & $\begin{array}{l}\text { Other } \\
\text { Sources }\end{array}$ & Conflict & Cost & Subcontract & Cost & Poor Perform & Delays \\
\hline $\begin{array}{l}20 \\
11 \\
\end{array}$ & Software & $\begin{array}{l}\text { Other } \\
\text { Sources }\end{array}$ & $\begin{array}{l}\text { Chan } \\
\text { ge } \\
\text { Orde } \\
\text { r } \\
\end{array}$ & $\begin{array}{l}\text { Risk of } \\
\text { Failure/Term } \\
\text { ination } \\
\end{array}$ & $\begin{array}{l}\text { High } \\
\text { Cost }\end{array}$ & Delay & $\begin{array}{l}\text { Poor } \\
\text { Perfo } \\
\text { rm } \\
\end{array}$ & $\begin{array}{l}\text { Defn of } \\
\text { Accept }\end{array}$ & Conflict & Subcontract & $\begin{array}{l}\text { Wrong } \\
\text { Product } \\
\end{array}$ \\
\hline 20 & Software & Cost & Othe & Delays & Defn of & Change & Poor & Conflict & Risk & Wrong & Subcon \\
\hline
\end{tabular}




\begin{tabular}{|c|c|c|c|c|c|c|c|c|c|c|c|}
\hline 06 & & & $\begin{array}{l}\text { r } \\
\text { Sour } \\
\text { ces }\end{array}$ & & Accept & Order & $\begin{array}{l}\text { Perfo } \\
\mathrm{rm}\end{array}$ & & $\begin{array}{l}\text { Failure/Term } \\
\text { ination }\end{array}$ & Product & tract \\
\hline $\begin{array}{l}20 \\
11\end{array}$ & Leases & $\begin{array}{l}\text { Other } \\
\text { Sources }\end{array}$ & $\begin{array}{l}\text { Chan } \\
\text { ge } \\
\text { Orde } \\
\text { r }\end{array}$ & Poor Perform & $\begin{array}{l}\text { High } \\
\text { Cost }\end{array}$ & Delay & $\begin{array}{l}\text { Risk } \\
\text { of } \\
\text { Failu } \\
\text { re }\end{array}$ & Conflict & $\begin{array}{l}\text { Defn of } \\
\text { Accept }\end{array}$ & $\begin{array}{l}\text { Wrong } \\
\text { Product }\end{array}$ & $\begin{array}{l}\text { Subcon } \\
\text { tract }\end{array}$ \\
\hline $\begin{array}{l}20 \\
06\end{array}$ & Leases & Cost & $\begin{array}{l}\text { Othe } \\
\text { r } \\
\text { Sour } \\
\text { ces }\end{array}$ & Delays & $\begin{array}{l}\text { Poor } \\
\text { Perform }\end{array}$ & $\begin{array}{l}\text { Defn of } \\
\text { Accept }\end{array}$ & $\begin{array}{l}\text { Chan } \\
\text { ge } \\
\text { Orde } \\
\text { r }\end{array}$ & Conflict & $\begin{array}{l}\text { Risk of } \\
\text { Failure/Term } \\
\text { ination }\end{array}$ & Subcontract & $\begin{array}{l}\text { Wrong } \\
\text { Product }\end{array}$ \\
\hline $\begin{array}{l}20 \\
11\end{array}$ & $\begin{array}{l}\text { Constru } \\
\text { ction }\end{array}$ & $\begin{array}{l}\text { Change } \\
\text { Order }\end{array}$ & $\begin{array}{l}\text { Dela } \\
\text { ys }\end{array}$ & $\begin{array}{l}\text { Defn of } \\
\text { Accept }\end{array}$ & $\begin{array}{l}\text { Poor } \\
\text { Perform }\end{array}$ & High Cost & $\begin{array}{l}\text { Conf } \\
\text { lict }\end{array}$ & $\begin{array}{l}\text { Risk of } \\
\text { Failure/Term } \\
\text { ination }\end{array}$ & Subcontract & $\begin{array}{l}\text { Wrong } \\
\text { Product }\end{array}$ & $\begin{array}{l}\text { Other } \\
\text { Sources }\end{array}$ \\
\hline $\begin{array}{l}20 \\
06\end{array}$ & $\begin{array}{l}\text { Constru } \\
\text { ction }\end{array}$ & $\begin{array}{l}\text { Change } \\
\text { Order }\end{array}$ & $\begin{array}{l}\text { Dela } \\
\text { ys }\end{array}$ & Cost & $\begin{array}{l}\text { Subcon } \\
\text { tract }\end{array}$ & Conflict & $\begin{array}{l}\text { Defn } \\
\text { of } \\
\text { Acce } \\
\text { pt }\end{array}$ & Poor Perform & $\begin{array}{l}\text { Risk of } \\
\text { Failure/Term } \\
\text { ination }\end{array}$ & $\begin{array}{l}\text { Wrong } \\
\text { Product }\end{array}$ & $\begin{array}{l}\text { Other } \\
\text { Sources }\end{array}$ \\
\hline
\end{tabular}

\section{Reported occurrence of contract problems over all types of contracts}

To determine which types of contract problems were reported to be most common across all types of contracts column means were computed for each type of problem. The overall mean for each type of problem was determined by computing the weighted mean of the seven contract type means.

Change orders were the most common contract administration problem while wrong product was the least common. The means for the contract problems in rank order are displayed in Table 7.

Table 6. Perceived occurrence of contract administration problems over all types of contracts 2011 Survey

\begin{tabular}{|l|l|}
\hline Contract administration problem & 2011 Mean \\
\hline Change Order & 2.69 \\
\hline Other Sources & 2.39 \\
\hline Delays & 2.36 \\
\hline Poor Performance & 2.23 \\
\hline Cost & 2.17 \\
\hline Risk of Failure & 2.11 \\
\hline Definition of Acceptance & 2.10 \\
\hline Conflict & 1.98 \\
\hline Subcontractors & 1.76 \\
\hline Wrong Product & 1.47 \\
\hline
\end{tabular}




\section{Reported occurrence of contract problems over all types of problems}

To determine which type of contract had the greatest reported occurrence of problems, row means were computed for each type of contract. That is, the overall mean for each type of contract was determined by computing the weighted mean of the ten contract problem means. Overall, Supplies and Small purchase contracts were reported as most likely to have contract problems whereas Software were reported as least likely to have contract problems. The means for the seven types of contracts are displayed in Table 8 ordered from most problematic to least.

Table 7. Perceived occurrence of contract administration problems by type of contract

\begin{tabular}{|l|l|}
\hline \multicolumn{1}{|c|}{ Contract type } & 2011 Mean \\
\hline Supplies, Small Purchases & 2.34 \\
\hline Construction & 2.28 \\
\hline Capital Outlay & 2.18 \\
\hline Professional Services & 2.15 \\
\hline Contracted Services & 2.11 \\
\hline Leases & 1.71 \\
\hline Software & 1.64 \\
\hline
\end{tabular}

Comparison of 2011 and 2006 Reported Occurrence of Contract problems over All Types of Contracts

Rankings from 2011 and 2006 on which problems are experienced most frequently show 3 of the top 4 problems were the same. In 2011, Other Sources identified as the 2nd most common problem whereas in 2006 it is the 7th most common problem. The respective ranking of contract problems is illustrated in Table 8. The correlation between the 2011 and 2006 ranks is .64 which is a strong correlation. A strong correlation means that the two sets of ranks are quite similar. 
Table 8. Comparison of 2011 and 2006 Reported Occurrence of Contract Problems Over All Types of Contracts

\begin{tabular}{|l|l|l|l|}
\hline $\mathbf{2 0 1 1}$ & \multicolumn{2}{|l|}{2006} & Rank \\
\hline Contract problem & Rank & Contract problem & 3 \\
\hline Change Order & 1 & Change Order & 7 \\
\hline Other Sources & 2 & Other Sources & 1 \\
\hline Delays & 3 & Delays & 4 \\
\hline Poor Performance & 4 & Poor Performance & 2 \\
\hline Cost & 5 & Cost & 9 \\
\hline Risk of failure & 6 & Risk of Failure & 5 \\
\hline Definition of Acceptance & 7 & Definition of Acceptance & 6 \\
\hline Conflict & $\mathbf{8}$ & Conflict & 8 \\
\hline Subcontractors & 9 & Subcontractors & 10 \\
\hline Wrong Product & 10 & Wrong Product \\
\hline
\end{tabular}

\section{Comparison of 2011 and 2006 Reported occurrence of contract problems by type of contract}

Rankings from the 2011 and 2006 surveys of which type of contracts experienced problems most often show very different results. The results are summarized in Table 9. The significant findings are that 2011 respondents reported more problems in Supplies and Small Purchases contracts and fewer problems in Contracted Services contracts than the 2006 respondents. The correlation between the 2011 and 2006 ranks is .21 which is not a very strong correlation a weak correlation means that while they are positively related, the relationship is not. 


\section{Macrothink}

Table 9. Comparison of 2011 and 2006 Reported Occurrence of Contract Problems by Contract Type

\begin{tabular}{|l|l|l|l|}
\hline 2011 & 2006 \\
\hline Contract Type & Rank & Contract Type & Rank \\
\hline Supplies, Small Purchases & 1 & Supplies, Small Purchases & 6 \\
\hline Construction & 2 & Construction & 1 \\
\hline Capital Outlay & 3 & Capital Outlay & 5 \\
\hline Professional Services & 4 & Professional Services & 3 \\
\hline Contracted Services & 5 & Contracted Services & 2 \\
\hline Software & 7 & Software & 4 \\
\hline Leases & 6 & Leases & 7 \\
\hline
\end{tabular}

\section{Consequences of problems for contract types}

These results reflect the respondents' reported consequences of problems by contract type. Table 10 summarizes the frequency and the computed percentage of six consequences for each contract type: no effect; delays of less than 10 days; delays of more than 10 days; cost increase of less than 10\%; and cost increase of more than $10 \%$. The percentage for each type of consequence is based on the total frequency of consequences for each type of contract, found in the final column labeled Row Frequency Total. With the exception of professional services and contracted services the results can be summarized by observing that when contract problems occurred, the respondents reported that for most contract types no consequences were more likely than problematic consequences. In the 2011 survey problematic consequences were most likely for construction contracts, occurring $74.70 \%$ of the time, and least likely for lease contracts, occurring $41.10 \%$ of the time.

\section{Comparison of Summary of Problematic Consequences in 2011 and 2006}

Both surveys show a majority of the contracts experience a greater percentage of problematic consequences than no consequence. In 2011 respondents reported fewer problematic consequences for Contracted Services and Software. 


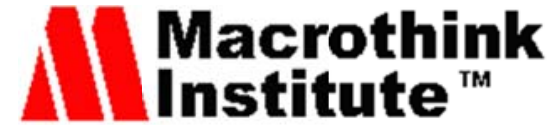

Table 10. Comparison of summary of Problematic Consequences in Canada and United States

\begin{tabular}{|c|c|c|c|c|c|c|}
\hline \multirow[b]{3}{*}{ Contract Type } & \multicolumn{2}{|l|}{2011} & \multicolumn{2}{|l|}{2006} & \multirow{2}{*}{\begin{tabular}{|l|}
2011 \\
No
\end{tabular}} & \multirow{2}{*}{\begin{tabular}{|l|}
2006 \\
No \\
\end{tabular}} \\
\hline & Problematic & & Problematic & & & \\
\hline & Consequences & Rank & Consequences & s Rank & Consequence & Consequence \\
\hline Construction & $74.70 \%$ & 1 & $68.90 \%$ & 1 & $25.30 \%$ & $31.10 \%$ \\
\hline $\begin{array}{l}\text { Supplies and Smal } \\
\text { Purchases }\end{array}$ & $166.00 \%$ & 2 & $62.90 \%$ & 4 & $34.00 \%$ & $37.10 \%$ \\
\hline Capital Outlay & $64.20 \%$ & 3 & $59.20 \%$ & 6 & $35.80 \%$ & $40.80 \%$ \\
\hline Professional Services & $64.00 \%$ & 4 & $64.20 \%$ & 3 & $36.00 \%$ & $35.80 \%$ \\
\hline Contracted Services & $58.10 \%$ & 5 & $64.40 \%$ & 2 & $41.90 \%$ & $35.60 \%$ \\
\hline Software & $48.20 \%$ & 6 & $60.30 \%$ & 5 & $41.80 \%$ & $39.70 \%$ \\
\hline Lease & $41.10 \%$ & 7 & $45.50 \%$ & 7 & $58.90 \%$ & $54.50 \%$ \\
\hline
\end{tabular}

\section{Summary, Conclusions and Implications}

The major findings were that the 2011 response rate was significantly higher than 2006, the overall results for problematic consequences were comparable to 2006 , in the that when contract administration problems occurred, problematic consequences were more likely than no consequences for all contract types except leases, and that the types of problematic consequences that were most likely depended on the type of contract. The overall results of 2011 and 2006 reported occurrence of contract problems by type of contract had a low correlation. In 2011 Other Sources was listed as the 2nd most frequently occurring problem while in 2006 Other Sources was the 7th most frequently occurring problem (Table 8) . This could be attributed to the decline in economic conditions possibly resulting in fewer suppliers available for each type of contract. In 2011 Supplies and Small Purchases was listed as the contract having the most problems (Table 9)and in 2006 Supplies and Small Purchase was the 6th most problematic contract. Historically, Supplies and Small purchase contracts typically had numerous providers. However, the same economic decline may have led to fewer available vendors, thereby increasing the potential for opportunism and more problems with the remaining vendors.

\section{Managerial Implications}

This new research supports the 2006 research conducted by Davison and Sebastian (Davison-Sebastian 2007) that data is available for, each type of contract, on the likelihood of contract administration problems occurring and the consequences of these problems if they do occur. By using this data the procurement professional can utilize a traditional risk management processes to determine an overall risk factor for each problem and then develop proactive risk mitigation plans that are based on eliminating or reducing each of the previously identified risks, or problems that have been identified as high combined risk. The contracting officer can perform a risk analysis to identify causal risk factors, such as poor specifications, project manager, time frame, etc, and then utilize the proactive contract administration 
planning tools, that were discussed earlier in this paper, to avoid or minimize the consequences of any contract administration problems instead of wasting valuable resources reacting to problems. The procurement process, especially the pre award activities, can be viewed as a critical component of any risk mitigation plan. With knowledge of the existing procurement process and information on potential problems, the procurement official can develop a risk mitigation plan by selecting the best option at each stage of the procurement process to achieve the overall goal of successful project completion--receiving the correct product at the correct time at the correct price without delays or cost overruns. This will allow procurement officials to demonstrate they are providing value (contract and project management) to the project beyond traditional bid and award function and are contributing to project savings by avoiding future costs (fewer delays and cost overruns), thereby demonstrating the strategic value of procurement.

\section{Practical Uses of Data}

Table 11 lists the data collected on the consequences of the most frequently reported problem (change order) on each type of contract. From the table the reader can ascertain that for Construction contracts, if a change order occurs, it will have a consequence $94.3 \%$ of the time and would result in increased costs $57.7 \%$ of the time and in contract delays $45.4 \%$ of the time. These could be very useful data when developing a risk mitigation plan. The procurement department could identify the potential root causes for change orders (incomplete specifications, unknown site conditions, changing market, managerial oversight) and reduce or eliminate them by developing better specifications and vendor qualification requirements.

Table 11. Consequences of Change Order (Highest Reported Occurring Problem) by Contract Type

\begin{tabular}{|c|c|c|c|c|c|c|c|c|c|c|c|c|c|}
\hline \multirow[b]{2}{*}{ Type of Contract } & \multicolumn{2}{|c|}{ No effect } & \multicolumn{2}{|c|}{$\begin{array}{l}\text { Contract } \\
\text { Delay } \\
<10 \text { days }\end{array}$} & \multicolumn{2}{|c|}{\begin{tabular}{|l} 
Contract \\
Delay \\
$>10$ days
\end{tabular}} & \multicolumn{2}{|c|}{\begin{tabular}{|l} 
Increased \\
Cost \\
$<10 \%$
\end{tabular}} & \multicolumn{2}{|c|}{$\begin{array}{l}\text { Increased } \\
\text { Cost } \\
>10 \%\end{array}$} & \multicolumn{2}{|c|}{ Termination } & \multirow{2}{*}{ 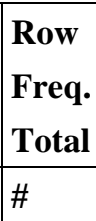 } \\
\hline & $\%$ & $\#$ & $\%$ & $\#$ & $\%$ & $\#$ & $\%$ & $\#$ & $\%$ & $\#$ & $\%$ & $\#$ & \\
\hline $\begin{array}{l}\text { Supplies and } \\
\text { Small Purchases }\end{array}$ & $14.9 \%$ & 265 & $17.1 \%$ & 305 & $22.1 \%$ & 393 & $24.0 \%$ & 428 & $19.8 \%$ & 353 & $2.1 \%$ & 37 & 1781 \\
\hline Capital Outlay & $17.6 \%$ & 211 & $17.5 \%$ & 210 & $21.9 \%$ & 263 & $22.0 \%$ & 264 & $18.7 \%$ & 224 & $2.3 \%$ & 27 & 1199 \\
\hline $\begin{array}{l}\text { Professional } \\
\text { Services }\end{array}$ & $14.2 \%$ & 168 & $15.9 \%$ & 188 & $23.8 \%$ & 282 & $22.5 \%$ & 267 & $22.4 \%$ & 266 & $1.3 \%$ & 15 & 1186 \\
\hline $\begin{array}{l}\text { Contracted } \\
\text { Services }\end{array}$ & $21.8 \%$ & 166 & $18,1 \%$ & 138 & $17.2 \%$ & 131 & $24.1 \%$ & 184 & $15.7 \%$ & 120 & $3.1 \%$ & 24 & 763 \\
\hline Software & $25.6 \%$ & 17 & $15.5 \%$ & 108 & $20.8 \%$ & 145 & $19.1 \%$ & 133 & $16.4 \%$ & 114 & $2.6 \%$ & 18 & 696 \\
\hline Lease & $38.7 \%$ & 145 & $15.2 \%$ & 57 & $14.7 \%$ & 55 & $19.2 \%$ & 72 & $10.9 \%$ & 41 & $1.3 \%$ & 5 & 375 \\
\hline Construction & $5.7 \%$ & 51 & $19.7 \%$ & 177 & $25.7 \%$ & 231 & $24.8 \%$ & 223 & $22.9 \%$ & 206 & $1.1 \%$ & 10 & 898 \\
\hline
\end{tabular}




\section{Future Research}

The data collected on frequency of contract problem occurrence and severity of consequences could be used as a benchmark against which to measure progress in procurement and vendor performance. For example, it would be possible to use the data for developing tools for Vendor Performance Measurement by using typical contract administration problems and consequences as baselines and monitoring vendor performance to see if problems occur or don't, If Construction contracts experience contract delays $45.4 \%$ of the time, a performance incentive could be provided if a vendor exceeds that performance. The same would be true for measuring the Procurement department's performance in a specific contract that meets or exceeds the baseline. The Procurement department could also use the data to develop risk mitigation plans for specific contracts and problems that are most problematic. The data could be used to establish validity of using existing contract management tools identified in private sector for managing contracts to the public sector, such as, incorporating the use of Critical Success Factors (CSF) and Integrated Risk Management into contract management. Future research could examine the effects of experience, certifications, education, size of purchasing unit, etc. on the types of problems experienced and types of contracts that are problematic.

\section{References}

Abi-Karam, T. (2001). Risk Management in Design Build. Paper presented at the International Conference on Construction in the $21^{\text {st }}$ Century, April 25-26, 2002, in Miami, Florida.

Amberg, Michael, Fischl, Florian, \& Wiener, Martin. (2005). Background of Critical Success Factors Research Working Paper 2-2205, Retrieved May 20, 2012, from https://docs.google.com/viewer?a=v\&q=cache:BHg7oxo0QNUJ:pdf.aminer.org/000/245/894 /critical_success_factors_csfs_and_the_growth_of_it_in.pdf $+\& h l=e n \& g l=u s \& p i d=b l \& s r c i d=$ ADGEESgXpJ-SUYc8OYx2-nnoiQ57P2Fy2I1HRDmeJfmzw7ZCP2OdJLqeVNYQwpO9g YdXElSfPX2XJS5_R3VvLcj9bM6Ba-OZfaEVpAP6OW7Srx4bDbAg6gGp-91GI4UWlIBnP CCi7Wg7\&sig=AHIEtbRr387eOrGTtz_f6pbVFeCibdws9g

Amirkhanyan, Anna. (2008) What is the Effect of Performance Measurement on Perceived Accountability Effectiveness in State and Local Government Contracts, Retrieved May 15, 2012, from http://www.maxwell.syr.edu/uploadedFiles/conferences/pmrc/Files/Amirkhanyan_What\%20i s\%20the\%20Effect\%20of\%20Performance\%20Measurement\%20on\%20Perceived\%20Acco untability\%20Effectiveness\%20in\%20State\%20and\%20Local\%20Government\%20Contracts .pdf

Ancona, D., Kochan, T. A., Scully, M., Van Maanen, J., \& Westney, D. E. (2005). Managing for the Future: Organizational Behavior \& Processes ( $3^{\text {rd }}$ ed.). South-Western College Publishing; Boston, MA

Baccarini, David, \& Collins, Adam. (2003). Critical success factors for projects. Retrieved on April

20 ,

2012,

from 
http://espace.library.curtin.edu.au/R/?func=dbin-jump-full\&object_id=203i33\&local_base=G EN01-ERA02

Bartle, J. R., \& LaCourse Korosec, R. (2001). Procurement and Contracting in State Government (A Report of the Government Performance Project). Syracuse University, The Maxwell School Campbell Public Affairs Institute; Syracuse, NY

Davison, B., \& Sebastian, R.J. \& Public Works and Government Services Canada (PWGSC), (2011) Transferability of Research on Persistent Risks in Supplier Engagement and Contract, Journal of Management Research, 3(2), Retrieved February 2, 2012 from http://www.google.com/url?sa=t\&rct=j\&q=\&esrc=s\&frm=1\&source=web\&cd=1\&ved=0CD cQFjAA\&url=http\%3A\%2F\%2Fwww.macrothink.org\%2Fjournal\%2Findex.php\%2Fjmr\%2F article\%2Fdownload\%2F575\%2F471\&ei=YF3OUJKyEOeqywGM1oCIAQ\&usg=AFQjCN G5azReMvOfKW4otvJK1mzlHTXb5Q\&sig2=X4OUQgBW-QySLjj9svxk1g\&bvm=bv.1355 325884,d.aWc

Davison, B., \& Sebastian, R. J. (2011). The relationship between contract administration problems and contract type. Journal of Public Procurement, 11(1), Boca Roton FL, PrAcademics Press

Davison, B., \& Sebastian, R. J. (2009). A detailed analysis of the relationship between contract administration problems and contract type. Journal of Public Procurement, 9 (2), Boca Roton FL, PrAcademics Press,

Davison, B., \& Wright, E. (2004). Contract Administration (CA). Washington D.C.: National Institute of Government Purchasing.

Dobbins, James H., \& Donnelly Richard G. (1998). Summary Research on Critical Success Factors in Federal Government Program Management. Retrieved April 20, 2012, from: https://docs.google.com/viewer?a=v\&q=cache:JzUxFFcZytQJ:www.dau.mil/pubscats/PubsC ats/AR\%2520Journal/arq98/dobbins.pdf+\&hl=en\&gl=us\&pid=bl\&srcid=ADGEESiHUaHBc Z5ET5V4iLhvibH_-MLJPnr-oruB8Ne0amesy2LfDYq5TL0xxlso8NUSJxNYqRRbBZL6Kd kD3MOtFDzhG_sjk6q8D37q8emlTLQ_yJlSb7iY0518OMDh75iwF-EIif_n\&sig=AHIEtbTT FlnhcbGMbWS_U6F3QQDcCI82w

Drabkin, D., \& Thai, K. V. (2003). U.S. Federal Government Procurement: Structure, Process and Current Issues (IPSERA). International Purchasing and Supply Education and Research Association's Comparative Public Procurement Cases Workshop, Budapest Hungary.

Harris, Kathy (1998). Worst Practices? Discovering Knowledge in Failures (Publication ID Number KA-04-9834). Gartner Group, Stamford CT

Government Accountability Office (GAO). (2005, March). Contract Management: Opportunities to Improve Surveillance on Department of Defense Service Contracts (GAO-05-274). Washington, DC: Author. 
Government Accountability Office (GAO). (2007, January). Defense Acquisitions: Improved Management and Oversight Needed to Better Control DoD's Acquisition of Services (GAO-07-832T). Washington, DC: Author.

Government Accountability Office (GAO). (2009, January). High-Risk Series: An Update (GAO-09-271). Washington, DC: Author.

Government Accountability Office (GAO). (2009, March). Department of Defense: Additional Actions and Data Are Needed to Effectively Manage and Oversee DOD's Acquisition Workforce (GAO-09-342). Washington, DC: Author

Gordon, S.B., Zemansky, S.D. \& Sekwat, A., (2000). The Public Purchasing Profession Revisited. Journal of Public Budgeting, Accounting \& Financial Management, 12 (2): 248-271

Hinson, C., \& McCue C. P. (2004). Procurement Planning, Sourcing and Requirements Analysis, Herndon VA. National Institute of Government Purchasing.

Hood, C.C \& Rothstein, H., (2000) Business Risk Management in Government: Pitfalls and Possibilities, $\quad$ Retrieved April 10, 2012 from, http://papers.ssrn.com/sol3/papers.cfm?abstract_id=471221

Kalvet, T., \& Lember, V. (2005). Risks Management in Public Procurement for Innovation: The Case of the Nordic-Baltic Sea Cities, Retrieved April 25, 2012, from http://www.ippa.org/IPPC4/Proceedings/17SupplyChainManagement/Paper17-4.pdf

Malatest R.A., Associaties Ltd \& Ford, Gerald Advocacy. (2012). Vendor performance management study. January 2012 Canada Association of Management Consultants

McCue, C. P., \& Gianakis, G. A. (2001). Public Purchasing: Who’s Minding the Store? Journal of Public Procurement, 1(1), 71-95, Boco Roton, PrAcademics Press.

McCue, C. P., \& Pitzer, J. T. (2005). Fundamentals of Leadership and Management in Public Procurement. Washington D.C, National Institute of Government Purchasing.

McCue, C. P., \& Pitzer, J. T. (2000). Centralized vs. Decentralized Purchasing: Current Trends in Governmental Procurement Practices. Journal of Public Budgeting, Accounting and Financial Management, 12(3), 400-420

National Institute of Government Purchasing (NIGP). (2000) Contract Management (CM) $1^{\text {st }}$ Edition. Washington D.C.: National Institute of Government Purchasing (NIGP).

Rendon, Rene G. (2010). Critical Success Factors in Government Contract Management, $\begin{array}{llll}\text { Retrieved } \quad \text { March } & \text { 20, from }\end{array}$ http://www.ippa.org/IPPC4/Proceedings/19Others/Paper19-2.pdf

Rendon, Rene G. (2006). Measuring Contract Management Process Maturity: A Tool for Enhancing the Value Chain. 91st Annual International Supply Management Conference, May 2006 
Schwartz, J. I. (2006) Regulation and Deregulation in Public Procurement Law Reform in the United States. Boca Raton, FL. PrAcademics Press.

Sherman, S. N. (1996). Government Procurement Management. Germantown, MD: Wordcrafters Publications.

Snyder, K.F. (2006) Procurement Leadership: From Means to End Journal of Public Procurement, 6(3), 274-294. Boca Roton FL. PrAcademics Press.

Thai, K.V. (2004) Introduction to Public Procurement (IPP). Washington D.C.: National Institute of Government Purchasing (NIGP). 